\title{
SOSIALISASI DETEKSI DINI KANKER SERVIKS DENGAN PEMERIKSAAN IVA (INSPEKSI VISUAL ASAM)
}

\author{
Erika Fariningsih ${ }^{1}$ \\ Ippa Ilmiya ${ }^{2}$ Indah Prima Cahyani ${ }^{3}$ Dikna Pasaribu ${ }^{4}$ \\ STIKes Awal Bros Batam \\ Program Studi D III Kebidanan STIKes Awal Bros Batam \\ 1ika.fn13@gmail.com
}

\begin{abstract}
ABSTRAK
Pemeriksaan IVA adalah sebuah pemeriksaan skrinning pada kanker serviks dengan menggunakan asam asetat 3-5\% pada inspekulo dan dapat dilihat dengan pengamatan secara langsung, cara ini dilakukan untuk melihat perubahan warna yang terjadi pasca dilakukan olesan, perubahan warna ini dapat langsung di amati setelah 1-2 menit pasca pengolesan dengan mata telanjang. Prosedur pelaksanaan test IVA cukup sederhana sehingga pemeriksaan ini bisa dilakukan oleh tenaga kesehatan selain dokter ginekologi. Tujuan dari pemeriksaan IVA untuk mengurangi morbiditas atau mortalitas dari penyakit dengan pengobatan dini terhadap kasus-kasus yang ditemukan dan untuk mengetahui kelainan yang terjadi pada leher rahim. Peserta pengabdian kepada masyarakat ini adalah ibu-ibu yang sudah menikah dan pernah melakukan hubungan seksual, wanita usia subur yang berada di RW 08 RT 04 Kampung Jabi Kecamatan Nongsa Kota Batam. Dalam pelaksanaan pengabdian kepada masyarakat ini terlebih dahulu kami tim pengabdian kepada masyarakat melakukan observasi dan studi pendahuluan guna untuk memperoleh informasi dan data kemudian kami melakukan sosialisasi terkait deteksi dini kanker serviks dengan pemeriksaan IVA. Hasil dari kegiatan pengabdian kepada masyarakat ini adalah peserta dapat memahami materi yang disampaikan dan mau melakukan pemeriksaan tes IVA guna pencegahan dini kanker serviks dan dari 20 peserta yang mengisi post test didapatkan 13 peserta memiliki pengetahuan baik.
\end{abstract}

Kata Kunci : Pengetahuan, Deteksi Dini, Kanker Serviks, Pemeriksaan IVA

\begin{abstract}
The IVA examination is a screening examination for cervical cancer using 3-5\% acetic acid on inspecules and can be seen by direct observation. This method is done to see the color change that occurs after applying the smear, this color change can be observed immediately after 1-2 minutes after application with the naked eye. The procedure for implementing the IVA test is quite simple so that this examination can be carried out by health workers other than gynecologists. The purpose of IVA examination is to reduce morbidity or mortality from the disease with early treatment of cases found and to determine abnormalities that occur in the cervix. Participants of this community service are mothers who are married and have had sexual relations, women of childbearing age who are in RW 08 RT 04 Kampung Jabi, Nongsa District, Batam City. In the implementation of this community service, our community service team first conducted observations and preliminary studies in order to obtain information and data, then we conducted socialization related to early detection of cervical cancer by IVA examination. The result of this community service activity is that participants can understand the material presented and want to do an IVA test for early prevention of cervical cancer and of the 20 participants who filled out the post test, it was found that 13 participants had good knowledge.
\end{abstract}

Keywords: Knowledge, Early Detection, Cervical Cancer, IVA Examination 


\section{PENDAHULUAN}

Menurut WHO (2010) dalam Departemen Kesehatan Republik Indonesia (2015) sekitar 490.000 wanita di seluruh dunia didiagnosa menderita kanker serviks dan 240.000 kasus kematian wanita akibat kanker serviks dan $80 \%$ kasus terjadi di negara berkembang. Berdasarkan data dari Yayasan Peduli Kanker Serviks Indonesia tahun 2015 penderita kanker serviks di Indonesia mencapai 15.000 kasus. (Sukaca, 2015)

Dari data Dinas Kesehatan Kota Batam tahun 2016 tentang keikutsertan WUS pada pemeriksaaan IVA yaitu sejumlah 1.779 orang, dari hasil pemeriksaan terdapat 24 orang dengan hasil positif, 2 orang dicurigai kanker serviks 1 orang, yang krioterapi, dari jumlah sasaran 102.497 orang dengan target $3 \%$. Sedangkan hasil cakupan baru mencapai $1,35 \%$ berarti masih banyak wanita usia 30-60 tahun yang belum melaksanakan deteksi dini kanker serviks dengan IVA. (DinKes Kota Batam, 2016).

Berdasarkan data Puskesmas Kampung Jabi dari Bulan Juni sampai Desember 2018 terdapat jumlah wanita usia subur yang melakukan pemeriksaan IVA sebesar 99 orang dari capaian target tahun 2018 sebesar 393 orang

Salah satu faktor penyebab tingginya angka kejadian kanker serviks pada wanita akibat rendahnya cakupan deteksi secara dini akibat kurangnya informasi pada masyarakat. Deteksi dini pada kanker serviks ini merupakan sebuah terobosan yang inovatif dalam kesehatan untuk mengurangi angka kematian dan kesakitan akibat kanker tersebut (Depkes RI, 2015). Sebagian besar wanita yang didiagnosis kanker serviks tidak melakukan skrinning test atau menindak lanjuti setelah ditemukan hasil yang abnormal, selain itu biaya untuk pemeriksaan dini kanker serviks tersebut tidak murah, sehingga keterlambatan pemeriksaanpun terjadi akibat kurangnya pengetahuan pada masyarakat tentang kanker serviks, sehingga kesadaran untuk melakukan deteksi dini kanker serviks tidak dilaksanakan.

Deteksi dini kanker pada leher rahim tersebut sangat penting dilakukan, karena potensi kesembuhan akan sangat tinggi jika masih ditemukan pada tahap prakanker. Pencegahan kanker serviks dapat dilakukan dengan program deteksi dini (skrinning) dan pemberian vaksinasi. Tindakan pencegahan yang dapat dilakukan antara lain dengan Pap Smear (mengambil lendir serviks untuk dilakukan pemeriksaan di laboratorium), kolposkopi (pemeriksaan yang dilakukan dengan menggunakan teropong), biopsy (pemeriksaan dengan mengambil sedikit jaringan serviks yang dicurigai), dan IVA Test (Inspeksi Visual Asam Asetat). (Astrit, 2015)

Tes IVA adalah sebuah pemeriksaan skrinning pada kanker serviks dengan menggunakan asam asetat 3-5\% pada inspekulo dan dapat dilihat dengan pengamatan secara langsung. Berdasarkan hasil uji diagnostik, pemeriksaan IVA memiliki sensitifitas $84 \%$, spesifisitas $89 \%$, nilai duga positif $87 \%$, dan nilai duga negatif $88 \%$, sedangkan pemeriksaan pap smear memiliki sensitifitas 55\%, spesifisitas $90 \%$, nilai duga positif $84 \%$, dan nilai duga negatif $69 \%$, sehingga dari hasil tersebut dapat disimpulkan bahwa pemeriksaan IVA lebih cepat memberikan hasil sensitivitas yang tinggi. (Taufan, 2010)

\section{METODE}

Sosialisasi ini menggunakan metode pendidikan kesehatan yang dilakukan dengan bentuk penyuluhan kepada masyarakat. Tim pengambdian kepada masyarakat memberikan penyuluhan dengan media lembar balik dan leaflet, diakhir penyuluhan dilakukan tanya jawab dan post test.

\section{Moderator : Anggota 1}

Tugas

a. Membuka dan menutup acara

b. Memperkenalkan diri

c. Menetapkan tata tertib acara pengabdian kepada masyarakat

d. Memimpin diskusi, memandu jalannya kegiatan

e. Menyimpulkan kegiatan di akhir sosialisasi

\section{Pemateri : Erika Fariningsih}

Tugas

a. Menyajikan materi pengabdian kepada masyarakat

b. Menggali pengetahuan peserta mengenai topik pengabdian kepada masyarakat

c. Memberikan pengertian tentang hal-hal yang tidak dipahami peserta

d. Menjalin kerja sama dengan moderator, observer selama berjalannya acara sosialisasi

3. Observer : Anggota 2 dan Anggota 3

Tugas

a. Mengamati jalannya kegiatan 

b. Mencatat tanggapan atau pertanyaan yang dikemukakan peserta
c. Memberikan kuesioner post test
d. Membuat laporan hasil kegiatan
e. Mengevaluasi kegiatan

Kegiatan pengabdian kepada masyarakat memiliki sasaran yaitu ibu-ibu yang sudah menikah dan pernah melakukan hubungan seksual/ wanita usia subur di RW 08 RT 04 Kampung Jabi Kecamatan Nongsa Kota Batam. Harapan utama kegiatan pengabdian kepada peserta mengetahui pengertian, tanda dan gejala serta cara pencegahan kanker serviks, serta melakukan deteksi dini kanker serviks melalui pemeriksaan IVA.

Adapun tujuan dan target capaian dari pelaksanaan pengabdian kepada masyarakat ini adalah :

1. Keterkaitan dengan pemateri yang terlibat pengabdian kepada masyarakat

a.Mengaplikasikan ilmu yang diperoleh tentang deteksi dini kanker serviks dengan pemeriksaan IVA

b. Sebagai pengalaman nyata dalam melakukan kegiatan sosialisasi tentang deteksi dini kanker serviks dengan pemeriksaan IVA

2. Keterkaitan dengan perguruan tinggi

a. Bentuk Implementasi Tri Dharma Perguruan Tinggi melalui pengembangan ilmu kebidanan

b.Menemukan permasalahan nyata tentang pengetahuan deteksi dini kanker serviks

c. Mengimplementasikan teori dan ilmu untuk kepentingan masyarakat

3. Keterkaitan dengan masyarakat

a. Dapat membantu ibu-ibu yang sudah menikah, pernah melakukan hubungan seksual/ wanita usia subur untuk mendeteksi secara dini kanker serviks dengan pemeriksaan IVA

Peserta Pengabdian kepada masyarakat adalah ibu-ibu yang sudah menikah, pernah melakukan hubungan seksual/ wanita usia subur di RW 08 RT 04 Kampung Jabi Kecamatan Nongsa Kota Batam. pemateri pada Pengabdian kepada masyarakat ini adalah Erika Fariningsih dengan tiga orang anggota, yaitu Ippa Ilmiya, Indah Prima Cahyani dan Dikna Pasaribu

\section{HASIL DAN IMPLEMENTASI}

Pengabdian kepada masyarakat ini dilaksanakan di RW 08 RT 04 Kampung Jabi Kecamatan Nongsa Kota Batam dapat dinilai sudah berjalan dengan baik karena semua kegiatan yang dilakukan sesuai dengan waktu yang sudah ditentukan.

\section{Tahapan Persiapan}

Kami tim Pengabdian kepada masyarakat melakukan koordinasi dan disetujui untuk melakukan studi pendahuluan dengan instansi terkait yaitu dengan Dinas Kesehatan Kota Batam, Puskesmas Kampung Jabi dan para kader. Setelah mendapat hasil dari studi pendahuluan dan disepakati untuk memberikan sosialisasi tentang deteksi dini kanker serviks dengan pemeriksaan IVA, selanjutnya kami melakukan persiapan untuk melakukan sosialisasi dengan dibantu oleh kader untuk menginformasikan kepada masyarakat.

2. Tahapan Implementasi

Pelaksanaan kegiatan ini dilaksanakan pada Kamis, 11 April 2019, kegiatan ini diikuti oleh ibu-ibu yang sudah menikah, pernah melakukan hubungan seksual/ wanita usia subur di RW 08 RT 04 Kampung Jabi Kecamatan Nongsa Kota Batam. Pada saat penyampaian materi peserta aktif dalam diskusi dan mengajukan pertanyaan tentang deteksi dini kanker serviks dan tentang pemeriksaan IVA.

Di akhir sosialisasi diberikan post test, dan peserta bisa menjawab soal-soal yang diberikan.

3. Tahapan Evaluasi

Evaluasi dalam kegiatan ini adalah peserta dapat memahami materi yang disampaikan dan mau melakukan pemeriksaan IVA guna pencegahan dini kanker serviks. Dari hasil post test dari 20 peserta didapatkan 13 peserta memiliki pengetahuan baik, peserta berusia $30-40$ tahun, dengan pendidikan terakhir SMA dan merupakan ibu rumah tangga.

\section{PEMBAHASAN}

Setelah diberikan penyuluhan meliputi tentang pengertian, gejala, penyebab, diagnosis, pengobatan, pencegahan dan tujuan deteksi dini kanker serviks dan pemeriksaan IVA didapatkan pengetahuan yang baik dari ibu-ibu di RW 08 RT 04 Kampung Jabi Kecamatan Nongsa Kota 
Batam. Hal ini sesuai dengan hasil penelitian yang menunjukkan bahwa promosi kesehatan mampu meningkatkan pengetahuan ibu tentang kanker serviks untuk mendukung peningkatan perilaku deteksi dini (Ismarwati, Sutaryo, \& Widyatama, 2011). Penyuluhan dilakukan dengan 20 peserta dan setelah penyuluhan dilakukan post test dengan membagikan kuesioner tentang materi yang sudah disampaikan dan hasil dari post test tersebut 13 peserta memiliki pengetahuan yang baik, meskipun sebagian besar pengetahuan peserta baik dan mau melakukan pemeriksaan IVA akan tetapi masih ada 2 peserta yang merasa ragu untuk melakukan pemeriksaan IVA karena merasa kurang mengerti apa itu pemeriksaan IVA, tentunya kami dari tim pengabdian kepada masyarakat menjelaskan kembali tentang materi yang telah disampaikan agar peserta tidak ragu lagi untuk melakukan deteksi dini kanker serviks dengan pemeriksaan IVA.

Pengetahuan seseorang dipengaruhi oleh beberapa faktor antara lain tingkat pendidikan, pengalaman, keyakinan dan sosial budaya. Semakin tinggi tingkat pendidikan seseorang, maka akan semakin mudah untuk menerima informasi atau yang berkaitan dengan pengetahuan. Semakin banyak pengalaman seseorang tentang suatu hal, maka akan semakin bertambah pula pengetahuan seseorang akan hal tersebut (Notoatmodjo, 2012). Peserta kegiatan pengabdian masyarakat ini mayoritas memiliki tingkat pendidikan SMA, sehingga memiliki kemampuan untuk menerima informasi secara baik dan meningkatkan pengetahuan mereka tentang kanker serviks, deteksi dini kanker serviks dan pemeriksaan IVA. Peningkatan pengetahuan para peserta didukung oleh faktor pengalaman, dimana dikaitkan dengan usia peserta yaitu 30-40 tahun. Dengan banyaknya peserta yang berusia diatas 30-40 tahun menunjukkan bahwa mereka telah memiliki banyak pengalaman yang dikaitkan dengan kanker serviks seperti mendapatkan informasi dari berbagai sumber baik secara langsung dari berbagai pihak, maupun media massa.

\section{SIMPULAN}

Kegiatan sosialisasi dapat diselengarakan dengan baik dan berjalan lancar sesuai dengan rencana kegiatan yang telah disusun oleh tim pengabdian kepada masyarakat dan mayoritas peserta berpengetahuan baik serta mau melakukan deteksi dini kanker serviks dengan pemeriksaan IVA.

\section{SARAN}

Pelaksanaan sosialisasi dan pemeriksaan IVA hendaknya dapat dilakukan secara berkelanjutan di RW 08 RT 04 Kampung Jabi Kecamatan Nongsa Kota Batam

\section{DAFTAR PUSTAKA}

Astrit, 2015. Pemeriksaan IVA. Jakarta. Penerbit buku kedokteran

DepKes RI, 2015. Penderita Kanker Serviks di Indonesia Jakarta: Departement Kesehatan Republik Indonesia.

Dinas Kesehatan Kota Batam, 2016. Klasifikasi Penduduk Kanker Serviks Kota Batam, Kota Batam : Dinas Kesehatan Kota Batam

Ismarwati, Sutaryo, S., \& Widyatama, R. (2011). Promosi Kesehatan dalam Meningkatkan Pengetahuan, Sikap dan Perilaku Deteksi Dini Kanker Serviks pada Ibu-Ibu Anggota Pengajian. Berita Kedokteran Masyarakat

Notoatmodjo, S. (2012). Promosi Kesehatan dan Perilaku Kesehatan. Jakarta, Indonesia: Rineka Cipta.

Nugroho Taufan. 2010. Ilmu Kandungan Edisi Ketiga. Jakarta: PT Bina Pustaka Sarwono Prawiroharjo

Sukaca E. Bertiani. 2009. Cara Cerdas Menghadapi KANKER SERVIK (Leher Rahim). Yogyakarta: Genius Printika 
Gambar Sosialisasi Deteksi Dini Kanker Serviks dengan Pemeriksaan IVA

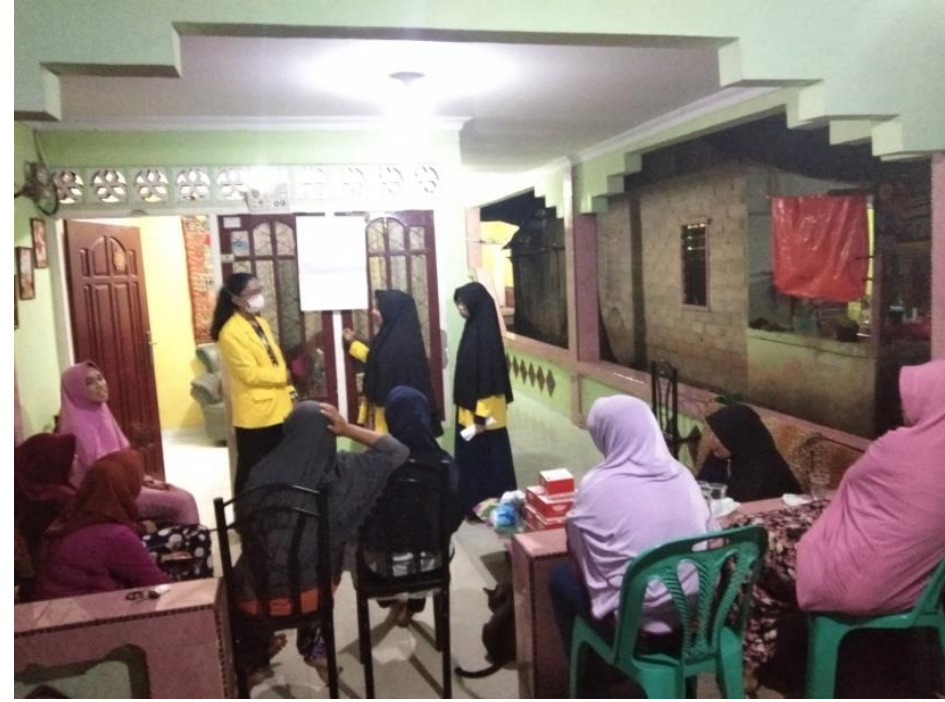

